\title{
ANALYSIS OF FUNCTIONAL CAPACITY IN INDIVIDUALS WITH AND WITHOUT CHRONIC LOWER BACK PAIN
}

\section{ANÁLISE DA CAPACIDADE FUNCIONAL EM INDIVÍDUOS COM E SEM DOR LOMBAR CRÔNICA}

\author{
Claudiane Pedro Rodrigues ${ }^{1}$, Rubens Alexandre da Silva ${ }^{1}$, Elias Nasrala Neto ${ }^{2}$, Rodrigo Antonio Carvalho andraus ${ }^{1}$, \\ Marcos Tadeu Parron Fernandes ${ }^{3}$, Karen Barros Parron Fernandes ${ }^{1,3}$ \\ 1. Universidade Estadual de Londrina (UEL)/Universidade Norte do Paraná (UNOPAR), Master's and Doctoral Program in Rehabilitation Sciences, Londrina, PR, Brazil. \\ 2. Universidade de Cuiabá, Cuiabá, MT, Brazil. \\ 3. Pontifícia Universidade Católica do Paraná, Londrina, PR, Brazil.
}

\begin{abstract}
Objective: The objective of this study was to analyze the functional status of adult and older adult individuals with lower back pain. Methods: Eighty-three individuals were recruited, 42 older adults (20 with lower back pain and 22 control group) and 41 younger adults (21 with lower back pain and 20 control group). Functional capacity was assessed using the following tests: Timed Up and Go (TUG), Five Times Sit-to-Stand (FTSTS), six-minute walking test (SMWT), and sitting-rising test (SRT). Results: In the younger adults, there was no difference in functional capacity between the groups ( $p>0.05)$. On the other hand, when statistical analysis was adjusted using body mass index (BMI) as a covariate, the lower back pain group performed more poorly on the SRT $(p<0.004)$. Furthermore, poorer physical capacity was seen in the older adults with back pain via the SRT test $(p=0.001)$, and when the BMI was adjusted, a statistical difference was seen in the SRT as well as the SMWT $(p<0.05)$. Conclusion: Older individuals with lower back pain have poorer physical performance, and the sitting-rising test is the most discerning for assessment of functional status in individuals with lower back pain. Level of Evidence III, Retrospective Comparative Study.
\end{abstract}

Keywords: Low back pain. Aged. Reproducibility of results.

\section{RESUMO}

Objetivo: Avaliar a funcionalidade de indivíduos idosos e jovens com dor lombar crônica. Método: Foram avaliados 83 indivíduos, sendo 42 idosos (Grupo controle: 22 e Grupo dor lombar: 20) e 41 jovens (Grupo controle: 20 e Grupo dor lombar: 21). Para avaliação da capacidade funcional, foram utilizados os testes Timed Up and Go (TUG), sentar e levantar de uma cadeira 5 vezes (Five Times Sit-to-Stand - FTSTS), o teste da caminhada dos seis minutos (TC6min) e sentar e levantar do solo (TSL). Resultados: Não houve diferença na capacidade funcional dos jovens entre os grupos ( $p$ $>0,05)$. Contudo, quando a análise é ajustada para a covariável "IMC", o Grupo dor lombar apresentou pior desempenho no teste TSL ( $p=0,004)$. No grupo de idosos, foi observado pior desempenho no Grupo dor lombar no teste TSL $(p=0,001)$. Após o ajuste pela variável "IMC", observou-se diferença estatística nas condições do teste TSL, assim como no TC6min ( $p<0,05)$. Conclusão: Idosos com dor lombar crônica apresentaram pior desempenho funcional e o teste TSL foi o mais discriminativo para avaliação funcional de indivíduos com dor lombar crônica. Nível de Evidência III, Estudo Retrospectivo Comparativo.

Descritores: Lombalgia. Idoso. Reprodutibilidade dos testes.

Citation: Rodrigues CP, Silva Júnior RA, Nasrala Neto E, Andraus RAC, Fernandes MTP, Fernandes KBP. Analysis of functional capacity in individuals with and without chronic lower back pain. Acta Ortop Bras. [online]. 2017;25(4):143-6. Available from URL: http://www.scielo.br/aob.

\section{INTRODUCTION}

Like a number of other developing countries, Brazil is undergoing a demographic shift, which is more evident in recent decades; the Brazilian population has been aging quickly since the early 1960 s. According to data from the Brazilian Institute of Geography and Statistics (IBGE), ${ }^{1}$ an increase in the population aged 65 years or over has been observed in this country, and it is estimated that by 2025 the elderly population could comprise $15 \%$ of the entire population. This fact is attributed to the chronic nature of diseases that lead to an increase in physical disabilities such as decline in health, decreased strength, reduced muscle endurance, flexibility, and mobility, as well as deterioration in motor control, causing postural instability in a variety of situations in daily life. ${ }^{2}$

The incidence of chronic degenerative diseases, namely chronic musculoskeletal pain, particularly in the lumbar region, is one of the most common complaints in individuals over age 60, and leads to functional limitation and greater physical dependence. ${ }^{3}$

Some of the tests used to evaluate functional capacity include the sitting-rising test (SRT), ${ }^{3}$ the Timed Up and Go (TUG) test, ${ }^{4}$ the six-minute walking test $(\mathrm{SMWT})^{5}$ and the Five Times Sit-to-Stand

All authors declare no potential conflict of interest related to this article.

Study conducted at Centro de Pesquisa em Ciências da Saúde da Universidade Norte do Paraná (UNOPAR), Avenida Marselha 591, Jardim Piza. - Londrina, PR, Brasil. 86041-140. Correspondence: Karen Barros Parron Fernandes. Centro de Pesquisa em Ciências da Saúde. Avenida Marselha 591, Jardim Piza, Londrina, PR, Brazil. 86041-140. karenparron@gmail.com 
test (FTSTS). ${ }^{6}$ These tests are notable because they are practical to implement and apply in clinical practice, have a low level of complexity, and do not require costly equipment.

The assessment of functional capacity is described in the literature in various populations. Puhan et al. ${ }^{7}$ assessed functional capacity in individuals with COPD using the SMWT and the FTSTS and concluded that these tests are able to assess functional capacity and would be responsive in pulmonary rehabilitation programs. Homann et al. ${ }^{8}$ reported the efficiency of the SMWT to determine the functionality of women with fibromyalgia by reducing the distance traveled during the test in the diseased group. Champagne et al. ${ }^{9}$ assessed balance and functional capacity in women with chronic lumbar pain in relation to several factors such as stiffness in the lumbar region, pain radiating to the buttocks, and pain in the lumbar region, and found that pain affects these individuals in relation to the risk of falls, mainly in elderly women.

Although different studies have applied functional tests, few address the population of individuals with chronic lumbar pain.

Considering the high prevalence and functional disability in different age groups resulting from chronic lumbar pain, new proposals to assess functional capacity are expected to help health professionals develop preventive programs and intervention, thus promoting an improvement in life expectancy and quality of life during the aging process. Functional capacity assessments can provide important information on the population with lumbar pain; this requires the use of instruments that assess motor function, muscle strength and aerobic resistance, flexibility, coordination, agility, and dynamic balance. These activities aim to ensure muscular and skeletal integrity in individuals, particularly in the elderly population, helping to reduce the risk of falls and functional disability, and in individuals recovering from chronic conditions.

Therefore, the objective of this study was to evaluate the functionality of elderly and younger individuals with chronic lower back pain, and to identify which tests are most discerning in analyzing the functional status of these individuals.

\section{MATERIALS AND METHODS}

This study is part of a multicenter research project (UNOPAR/UNIC), which was approved by the UNIC institutional review board (CEP $n^{\circ}$ $273,376)$. All participants signed a document indicating free and informed consent before tests were performed.

This study was observational, cross-sectional, descriptive, and used a quantitative approach.

The Bioestat 5.0 program was used to calculate the sample, using the data obtained from the study of Champagne et al. ${ }^{9}$ as parameters. The confidence interval was set at 95\%, alpha level at 5\% and test power at $80 \%$, and consequently a minimum sample of 16 individuals per group was required to test the null hypothesis that there is no difference between the sensory-motor properties of individuals with and without chronic lumbar pain. Considering possible losses, we recruited a $20 \%$ larger sample (20 subjects in each group).

We evaluated 83 individuals of both sexes in the local community of Londrina, Paraná, Brazil: 41 younger adults and 42 older adults. The participants were divided into four groups for analysis: 1) healthy young adults ( $\mathrm{G} 1 \mathrm{n}=20$ ); 2) young adults with chronic lumbar pain $(G 2, n=21) ; 3$ ) healthy older adults ( $G 3 n=22)$; 4) older adults with chronic lumbar pain $(\mathrm{G} 4, \mathrm{n}=20)$. Chronic lumbar pain determined via self-report and was defined as being of unknown mechanical origin and persisting for more than 3 months. We used data on the pressure pain threshold to confirm the presence of low back pain. The eligibility criteria for the groups with pain were: presence of lumbar pain with or without irradiation limited to the knees, measured by assessing the pressure pain threshold using a EGM Systems brand device; presence of chronic pain, defined as pain every day or nearly every day over the previous three months; lower back pain of unknown mechanical origin (muscle or passive structures); non-participation in rehabilitation programs, such as conventional physiotherapy, Pilates, or global postural re-education.

Inclusion criteria for the control group were lack of any lumbago or lower back pain radiating to the lower limbs; non-participation in physical activity programs more than three days per week in accordance with the recommendations of the American College of Sports Medicine, ${ }^{10}$ good overall health; be physically independent and voluntarily opt to participate in the study. The young adult participants were between 18 and 50 years of age and the older participants were 60 years or over.

Exclusion criteria for all groups were presence of any kind of neurological, respiratory, metabolic, and/or orthopedic disorder, rheumatic disease with bone or muscular impairment; vestibular disease or acute attacks of labyrinthitis; mental problems, attention and speech disorders; having undergone any type of surgery of the locomotor system; non-volunteer.

This study was conducted at the Universidade Norte do Paraná (UNOPAR) from August to December 2014. The assessments were conducted in just one day, always in the afternoon. Initially we collected sociodemographic and anthropometric data such as weight and height, and calculated body mass index (BMI).

Evaluation of pain to pressure threshold (PPT)

An EGM Systems brand device was used to measure PPT. The device measures pressure in $\mathrm{kgf}$ and has a rod at one end with a 1 $\mathrm{cm}^{2}$ flat circular end surface which applies constant and increasing pressure perpendicular to anatomic pressure points. ${ }^{11}$

\section{The sitting-rising test}

The sitting-rising test evaluates the functional mobility of older adults. In this test, the individual rises from the floor using as little support as possible, without concern for speed. Total score ranges from zero to 10 , with five points attributed to sitting and five points to rising from the floor. One point is subtracted for each support used; these can be the hands, knee, or the side of the leg, and half a point is deducted for loss of balance.

\section{Five Times Sit-to-Stand Test (FTSTS)}

This test is easy to administer and assesses leg strength, balance, and risk of falls. The patient is directed to cross his arms over his chest and sit with his back against the chair $(43 \mathrm{~cm}$ high, $47.5 \mathrm{~cm}$ deep). The examiner gives the following instructions according to the standard protocol: "I want you to stand up and sit down five times, as fast as you can, when I say 'Go.' "Timing begins when the examiner says "Go" and ends when the buttocks touch the chair after the fifth repetition.

\section{Timed Up and Go Test (TUG)}

This test assesses fall risk. Transfer from a seated position to standing is evaluated along with stability and gait changes without using compensatory strategies. The assessor asks the individual to get up from a chair where she/he was fully supported, walk three meters, turn around, return by the same route, and sit back down in the chair with his or her back supported; performance is measured as the time (in seconds) required to perform the test.

\section{Six-Minute Walk Test (SMWT)}

According to the recommendations of the American Thoracic Society (ATS) ${ }^{12}$ this self-paced test assesses the sub-maximal level of functional capacity on a 30-meter course marked by two cones at each end. This test measures the distance an individual can walk as quickly as possible without running on a flat, firm, covered surface 
for a period of six minutes. The individual is allowed to pause or rest during the test if necessary, but the timer does not stop.

The assessments were performed on the same day, always in the afternoon. The better score for each test was considered, except for the SMWT, which according to the ATS uses a 30-minute rest interval. All tests were applied twice, with a rest period of 1 minute between tests. The tests were applied in the following order: sitting-rising test, then Five Times Sit-to-Stand test, then the Timed Up and Go test, and last the six-minute walk test.

\section{Statistical analysis}

The data were analyzed descriptively and analytically using Statistical Package for Social Sciences software (SPSS) version 18.0. A confidence interval of $95 \%$ was established, along with a $5 \%$ significance level $(P<0.05)$ for all tests.

The Shapiro-Wilk test was used to test the normality of the data. To compare the four groups we used the t test for independent samples, considering normal distribution in the comparable subgroups.

Finally, the ANCOVA test was used to compare the groups in order to reduce the variance of the error and adjust the means of the covariate "body mass index" (BMI) for all subjects to a fixed value.

\section{RESULTS}

Eighty-three individuals participated in the study. The anthropometric characteristics were similar between the groups with regard to age, weight, height, BMI, and pain pressure threshold. (Table 1)

As for the presence of multiple morbidities and medication use in the population studied, the older adults exhibited a higher prevalence for these variables than the younger adults. (Table 2)

Table 1. Characteristics of the study population.

\begin{tabular}{|c|c|c|c|}
\hline \multicolumn{4}{|c|}{ Young adults } \\
\hline Variable & $\begin{array}{c}\text { Control } \\
\text { Mean } \pm \text { SD }\end{array}$ & $\begin{array}{l}\text { Lower back pain } \\
\text { Mean } \pm \text { SD }\end{array}$ & $\begin{array}{c}\text { Independent } \\
\text { t test }(P)^{*}\end{array}$ \\
\hline Age (years) & $30.75 \pm 10.86$ & $31.38 \pm 8.52$ & 0.837 \\
\hline Weight (kg) & $70.32 \pm 18.82$ & $75.76 \pm 11.26$ & 0.265 \\
\hline Height (m) & $1.67 \pm 0.73$ & $1.66 \pm 0.85$ & 0.679 \\
\hline $\begin{array}{l}\text { BMI }\left(\mathrm{kg} / \mathrm{m}^{2}\right) \text { Pressure } \\
\text { pain threshold (kgf) }\end{array}$ & $\begin{array}{c}24.73 \pm 5.14 \\
7.31 \pm 0.45\end{array}$ & $\begin{array}{c}27.23 \pm 3.55 \\
5.31 \pm 0.49\end{array}$ & $\begin{array}{l}0.076 \\
0.002^{*}\end{array}$ \\
\hline \multicolumn{4}{|c|}{ Older adults } \\
\hline Age (years) & $71.23 \pm 5.06$ & $69.42 \pm 5.67$ & 0.283 \\
\hline Weight (kg) & $66.41 \pm 8.48$ & $70.48 \pm 10.53$ & 0.176 \\
\hline Height $(\mathrm{m})$ & $1.56 \pm 0.57$ & $1.56 \pm 0.75$ & 0.732 \\
\hline $\begin{array}{l}\text { BMI }\left(\mathrm{kg} / \mathrm{m}^{2}\right) \text { Pressure } \\
\text { pain threshold (kgf) }\end{array}$ & $\begin{array}{c}27.40 \pm 3.90 \\
7.48 \pm 0.32\end{array}$ & $\begin{array}{c}28.83 \pm 4.90 \\
6.05 \pm 0.29\end{array}$ & $\begin{array}{l}0.303 \\
0.002^{*}\end{array}$ \\
\hline
\end{tabular}

No statistically significant difference in the functional performance of the younger adults was observed between the groups ( $p>0.05)$. But when the analysis was adjusted for the covariate BMI in this same population, the group with chronic lower back pain showed higher scores in the SRT ( $p>0.004)$, indicating functional limitation in mobility when rising from the ground. (Table 3)

In the older adults with and without chronic lower back pain, differences in functional performance were only observed in the SRT $(p=0.00)$. The group of older adults with pain demonstrated functional limitation in rising from the floor, which highlights the sensitivity of this test in describing functionality in relation to other tests used in the study.

When adjusted by the covariate BMI, the group of older adults with chronic lower back pain also showed differences in relation to the control group for both sitting and rising in the SRT and in the SMWT (ANCOVA, $p<0.05$ ); the older adults with pain showed reduced functional performance, as shown in Table 4.

\section{DISCUSSION}

In this present study no difference was seen between the control and pain groups in younger adults in terms of the relationship between functional capacity and lower back pain. However, the older adults with chronic lower back pain performed more poorly on functional tests than the older adults without lower back pain.

\begin{tabular}{|c|c|c|c|c|}
\hline Variable & $\begin{array}{c}\text { Control } \\
\text { Mean } \pm \text { SD }\end{array}$ & $\begin{array}{c}\text { Lower back pain } \\
\text { Mean } \pm \text { SD }\end{array}$ & $\begin{array}{c}\text { Independent } \\
t \text { test }(P)^{*}\end{array}$ & ANCOVA $(\mathrm{P})^{*}$ \\
\hline SRT (sitting) & $4.30 \pm 0.85$ & $4.42 \pm 0.50$ & 0.55 & 0.169 \\
\hline SRT (rising) & $3.4 \pm 0.81$ & $4.0 \pm 1.11$ & 0.87 & $0.004^{*}$ \\
\hline FTSTS & $10.29 \pm 2.05$ & $9.00 \pm 1.57$ & 0.50 & 0.825 \\
\hline TUG & $5.79 \pm 0.84$ & $5.70 \pm 0.70$ & 0.70 & 0.967 \\
\hline SMWT & $646.0 \pm 53.84$ & $630.95 \pm 55.88$ & 0.38 & 0.238 \\
\hline
\end{tabular}

SRT = sitting-rising test (from ground); FTSTS = Five Times Sit-to-Stand Test; TUG: Timed Up and Go; SMWT = six-minute walk test. $P<0.05^{*}$.

Table 4. Functional capacity results in older individuals.

\begin{tabular}{c|c|c|c|c}
\hline Variable & $\begin{array}{c}\text { Control } \\
\text { Mean } \pm \text { SD }\end{array}$ & $\begin{array}{c}\text { Lower back pain } \\
\text { Mean } \pm \text { SD }\end{array}$ & $\begin{array}{c}\text { Independent } \\
\mathbf{t} \text { test }(\mathbf{P})^{*}\end{array}$ & $\begin{array}{c}\text { ANCOVA } \\
(\mathbf{P})^{*}\end{array}$ \\
\hline SRT (sitting) & $3.04 \pm 0.92$ & $2.16 \pm 1.23$ & 0.12 & $0.000^{*}$ \\
\hline SRT (rising) & $2.69 \pm 1.03$ & $1.42 \pm 1.12$ & $0.00^{*}$ & $0.000^{*}$ \\
\hline FTSTS & $13.07 \pm 2.80$ & $14.97 \pm 3.35$ & 0.53 & 0.229 \\
\hline TUG & $7.17 \pm 1.31$ & $7.97 \pm 1.26$ & 0.52 & 0.16 \\
\hline SMWT & $523.09 \pm 85.91$ & $468.66 \pm 82.53$ & 0.43 & $0.001^{*}$ \\
\hline
\end{tabular}

SRT= sitting-rising test (from ground); FTSTS= Five Times Sit-to-Stand Test; TUG: Timed Up and Go; SMWT = six-minute walk test. $P<0.05^{*}$

Table 2. Characteristics of medication use and presence of multiple morbidities in the study population.

\begin{tabular}{|c|c|c|c|c|c|c|}
\hline \multicolumn{7}{|c|}{ Young adults } \\
\hline & \multicolumn{3}{|c|}{ Control } & \multicolumn{3}{|c|}{ Lower back pain } \\
\hline Variable & Category & Frequency absolute $(\mathrm{n})$ & Frequency relative (\%) & Category & Frequency absolute (n) & Frequency relative (\%) \\
\hline \multirow[t]{2}{*}{ Sex } & Female & 14 & $46.67 \%$ & Female & 16 & $53.33 \%$ \\
\hline & Male & 6 & $54.54 \%$ & Male & 5 & $45.46 \%$ \\
\hline Medication use & & 0 & 0 & & 2 & $9.5 \%$ \\
\hline Multiple morbidities & & 0 & 0 & & 0 & 0 \\
\hline \multicolumn{7}{|c|}{ Older adults } \\
\hline & \multicolumn{3}{|c|}{ Control } & \multicolumn{3}{|c|}{ Lower back pain } \\
\hline Variable & Category & Frequency absolute $(\mathrm{n})$ & Frequency relative (\%) & Category & Frequency absolute $(\mathrm{n})$ & Frequency relative (\%) \\
\hline \multirow[t]{2}{*}{ Sex } & Female & 18 & $48.65 \%$ & Female & 19 & $51.35 \%$ \\
\hline & Male & 4 & $80 \%$ & Male & 1 & $20 \%$ \\
\hline Medication use & & 3 & $14.3 \%$ & & 13 & $61.9 \%$ \\
\hline Multiple morbidities & & 9 & $42.9 \%$ & & 15 & $71.4 \%$ \\
\hline
\end{tabular}


Studies on aging have emphasized the search for strategies that can mitigate the deleterious consequences of the aging process on quality of life; aging is a physiological process and functional capacity in the elderly may be affected by several factors, since these individuals have more chronic health problems than younger people.

Although elderly patients with lumbar pain can use medications that act centrally or peripherally for pain control, we found that the vast majority of this sample did not use medication for pain on a continuous basis. These data agree with the study by Figueiredo et al., ${ }^{13}$ who reported that elderly individuals with lumbar pain only used medication when pain was acute. When we assessed the physical function and capacity of individuals with lower back pain, we found that lumbar pain in young people has no significant clinical repercussions, except in cases where the participant was also overweight or obese.

Lira et al. ${ }^{14}$ evaluated the acute effect of increased body weight on performance in the sitting-rising test among young, active adults and found that overweight status had a negative impact on test performance, and concluded that active overweight individuals performed worse in the activities performed (sitting down and standing up), in agreement with our findings.

This present study demonstrated that older adults with chronic lumbar pain performed more poorly on functional tests than the older adults without lower back pain. It can be assumed that the aging process, associated with incorrect posture and excess burden on the spine, are significant factors in triggering serious injury to the discs of the vertebra and mechanical or degenerative changes. The presence of pain has been described by some authors as a limiting factor in elderly individuals during performance of daily activities. ${ }^{15}$ In assessing functional capacity, we highlight the use of some functional evaluations such as the sitting-rising test (SRT), the six-minute walk test (SMWT), the Five Times Sit-to-Stand test (FTSTS), and the Timed Up and Go test.

In terms of performance in the SRT and SMWT, older individuals in both groups had much poorer performance compared to the younger adults, which is consistent with a study conducted by Lee et al., ${ }^{16}$ who found that individuals with chronic lower back pain tend to walk more slowly in the SMWT. Mascarenhas and Santos ${ }^{17}$ assessed the perception and intensity of pain and functional capacity in young and elderly people with chronic low back pain and found that pain in the lumbar region was not seen as a limiting factor in relation to daily activities, especially in younger individuals, which was also found by Bento et al. ${ }^{18}$ This latter finding explains that it is unusual for chronic lumbar pain to completely incapacitate an individual in terms of performing everyday activities, but this pain can partially and temporarily affect individuals, at times on a recurring basis, when individuals are economically active.

Camara et al. ${ }^{19}$ stated that the ability to rise from a chair or bed, even though it may be considered a simple task, is considered a complex action which may be related to musculoskeletal and neuromotor disorders which make significant demands of elderly individuals. For Silva et al. ${ }^{20}$ this is because of the exposure of the body when there is an extra load that the musculoskeletal system must support, and consequently may cause alterations to the biomechanical balance of the body.

\section{CONCLUSION}

The findings of this study provide evidence about the best strategy to evaluate the function of older adults with chronic lower back pain in order to reproduce the functional tests in daily clinical practice, being the SRT the most discerning for this population.

AUTHORS' CONTRIBUTIONS: Each author made significant individual contributions to this manuscript. CPR (0000-0001-7711-1217)*, RASJ (00000001-6879-436X)* ENN (0000-0002-2085-6717)*, RACA (0000-0002-3849-0872)*, MTPF (0000-0003-4494-0187) ${ }^{\star}$ e KBPF (0000-0002-1276-4900)* were the main contributors in drafting the manuscript. CPR, ENN e MTPF, performed the data collection, followed the individuals and collected the clinical data. RASJ e KBPF evaluated the data from the statistical analysis.RASJ, RACA e KBPF and contributed to the intellectual concept of the study. *ORCID (Open Researcher and Contributor ID).

\section{REFERENCES}

1. IBGE. Instituto Brasileiro de Geografia e Estatística. Síntese de indicadores sociais: uma análise das condições de vida da população brasileira 2010 [acesso em 2017 abr 9]. Disponível em: www.ibge.gov.br.

2. Carvalho AM, Coutinho ESF. Demência como fator de risco para fraturas graves em idosos. Rev Saúde Pública. 2002;36(4):448-54.

3. Araújo CGS. Teste de sentar-levantar: apresentação de um procedimento para avaliação em Medicina do Exercício e do Esporte. Rev Bras Med Esporte. 1999;5(5):179-82.

4. Podsiadlo D, Richardson S. The timed "Up \& Go": a test of basic functional mobility for frail elderly persons. J Am Geriatr Soc. 1991;39(2):142-8.

5. Ozalevli S, Ozden A, Itil O, Akkoclu A. Comparison of the Sit-to-Stand Test with 6 min walk test in patients with chronic obstructive pulmonary disease. Respir Med. 2007;101(2):286-93.

6. Whitney SL, Wrisley DM, Marchetti GF, Gee MA, Redfern MS, Furman JM. Clinical measurement of sit-to-stand performance in people with balance disorders:validity of data for the Five-Times-Sit-to-Stand Test. PhysTher. 2005;85(10):1034-45.

7. Puhan MA, Siebeling L, Zoller M, Muggensturm P, terRiet G. Simple functional performance tests and mortality in COPD. EurRespir J. 2013;42(4):956-63.

8. Homann D, Stefanello JM, Góes SM, Leite N. Impaired functional capacity andexacerbation of pain and exertion during the 6-minute walk test in women withfibromyalgia. Rev Bras Fisioter. 2011;15(6):474-80.

9. Champagne A, Prince F, Bouffard V, Lafond D. Balance, falls-related self-efficacy, and psychological factors amongst older women with chronic low back pain: a preliminary case-control study. Rehabil Res Pract. 2012;2012:430374.

10. Chodzko-Zajko WJ, Proctor DN, Fiatarone Singh MA, Minson CT, Nigg CR, Salem GJ, et al. American College of Sports Medicine position stand. Exercise and physical activity for older adults. Med Sci Sports Exerc. 2009;41(7):1510-30.

11. Reid KI, Gracely RH, Dubner RA. The influence of time, facial side, and location on pain-pressure thresholds in chronic myogenous temporomandibular disorder. J Orofac Pain. 1994;8(3):258-65.

12. Spruit MA, Singh SJ, Garvey C, ZuWallack R, Nici L, Rochester C, et al. An official American Thoracic Society/European Respiratory Society statement: key concepts and advances in pulmonary rehabilitation. Am J Respir Crit Care Med. 2013;188(8):e13-64.

13. Figueiredo VF, Pereira LSM, Ferreira PH, Pereira AM, Amorim JSC. Functional disability, depressive symptoms and low back pain in elderly. Fisioter Mov. 2013;26(3):549-57

14. Lira VA, Silva EB, Araújo CGS. As ações de sentar e levantar do solo são prejudicados por excesso de peso. Rev Bras Med Esporte. 2000;6(6):241-8.

15. Fielder MM, Peres KG. Capacidade funcional e fatores associados em idosos do sul do Brasil: um estudo de base populacional. Cad Saúde Pública. 2008;24(2):409-15

16. Lee CE, Simmonds MJ, Etnyre BR, Morris GS. Influence of pain distribution on gait characteristics in patients with low back pain: part 1: vertical groundreaction force. Spine (Phila Pa 1976). 2007;32(12):1329-36.

17. Mascarenhas CHM, Santos LS. Evaluation of pain and functional capacity in patients with chronic low back pain. J Health Sci Inst. 2011;29(3):205-8.

18. Bento AAC, Paiva ACS, Siqueira FB. Correlação entre incapacidade, dor - Roland Morris, e capacidade funcional - SF-36 em indivíduos com dor lombar crônica não específica. eScientia. 2009;2(1):1-18.

19. Camara FM, Gerez AG, Miranda MLJ, Velardi M. Capacidade funcional do idoso: formas de avaliação e tendências. Acta Fisiátrica. 2008;15(4):249-56.

20. Silva MC, Fassa AG, Valle NCJ. Dor lombar crônica em uma população adulta do Sul do Brasil: prevalência e fatores associados. Cad Saúde Pública. 2004;20(2):377-85. 